\title{
MODEL FULL DAY SCHOOL BERBASIS KECERDASAN MAJEMUK UNTUK MENINGKATKAN SPIRITUAL QUOTIENT SISWA DI SEKOLAH DASAR
}

\author{
Muh. Luqman Arifin ${ }^{1}$, dan Adnan Yusufi ${ }^{2}$ \\ ${ }^{1,2}$ Universitas Peradaban, Bumiayu \\ Email: 1uq c2003@yahoo.com; adnanyusufi1@gmail.com
}

\section{Info Artikel}

Sejarah Artikel:

Diserahkan 2 September 2019

Direvisi 24 November 2019

Disetujui 28 November 2019

\section{Keywords:}

full day school, multiple

intelligence, spiritual quotient

\section{Abstract}

This research was aimed to produce a draft of model full day school to improve the Spiritual Quotient students in elementary school.

The method this research used was a Research \& Development $(R \& D)$ served to develop and validate prototypes. Samples of the research were students of SDIT Al-Ambary, Bumiayu, SDIT Harapan Umat Brebes, and SDTQ Al-Ikhlas, Brebes which implemented full day school system. Data retrieval techniques in this research used a questionnaire methods, observations, tests and interviews. Data retrieval of this research used a product feasibility assessment instruments by the validator and test of spiritual intelligence to students.

The results of this research was a teaching book in an effort to improve the spiritual intelligence of students who were worthy of testing based on the assessment of the validator with an average yield of 4.3 or with the predicate "A" very good. And the test results of spiritual intelligence was given to students through the poll technique obtained an average result of 3.5 entering into "good" category.

\begin{abstract}
Abstrak
Tujuan penelitian ini adalah menghasilkan draf model belajar full day school (FDS) untuk meningkatkan Spiritual Quotient siswa Sekolah Dasar.

Metode yang digunakan adalah Research \& Development (R\&D) yang berfungsi untuk pengembangkan dan memvalidasi prototype. Sampel penelitian adalah siswa di SDIT AlAmbary, Bumiayu, SDIT Harapan Umat Brebes, dan SDTQ Al-Ikhlas, Brebes yang menerapkan sistem FDS. Teknik pengambilan data menggunakan wawancara, observasi, dan angket tes. Pengambilan data penelitian menggunakan instrumen penilaian kelayakan produk oleh validator dan tes kecerdasan spiritual terhadap siswa.

Hasil penelitian menunjukkan bahwa model yang berupa bahan ajar dalam meningkatkan kecerdasan spiritual siswa layak diujicobakan berdasarkan penilaian validator dengan hasil rata-rata 4,3 atau dengan predikat "A" Sangat Baik. Dan hasil tes kecerdasan spiritual kepada siswa melalui angket tes diperoleh hasil rata-rata 3,5 masuk kategori "Baik."
\end{abstract}

(C) 2019 Universitas Muria Kudus 


\section{PENDAHULUAN}

Bermunculannya Sekolah Dasar (SD) berbasis IT (Islam Terpadu) yang menerapkan sistem full day school di Indonesia juga diikutibeberapa sekolah di Kabupaten Brebes di antaranya SDIT Al-Ambari, SDTQ Al-Ikhlas, dan SDIT Harapan Umat.Perjalanan sistem ini pun sudah lama, yaitu pada tahun 1990-an yang dipelopori sekolah-sekolah swasta berbasis Islam, atau disebut sekolah 'unggulan'. (Sismanto, 2007).

Sekolah yang menerapkan FDS pun kian waktu kian bertambah jumlahnya, meski tidak ada data pasti, tetapi dari pengamatan di sejumlah daerah kentara pertambahannya. Dan kepeminanatan orang tua untuk menyekolahkan anaknya ke sekolah tersebut pun makin bertambah pula. Terdapat berbagai motif mengapa orang tua memilih sistem FDS, di antaranya adalah faktor kesibukan orang tua yang tidak memiliki cukup waktu membersamai sang anak. (Halik,2017). Alternatifnya, adalah FDS yang umumnya dilengkapi dengan kurikulum khas yang cakupan materi agamanya banyak dan waktunya yang lama dimanfaatkan dengan aktifitas pembiasaan keagamaan. Penggunaan waktu yang efektif diharapkan dapat memperbaiki karakter anak sekaligus mengurangi pergaulan yang tidak terkontrol dan tejerumus pada meningkatnya kenakalan.

Meski FDS menjadi idola dan pilihan orang tua, tetapi sistem ini pun tidak luput dari kritik dan kelemahan, yaitu kurangnya interaksi sosial yang berakikat pada rendahnya kepekaan sosial anak, anak akan menjadi lemah dalam membaca situasi dan jaringan sosial, tidak mampu menjalin komunikasi, dan tidak mampu bekerja sama dalam tim. (Nggermanto, 2002).Namun, FDS juga memiliki kelebihan seperti dalam penelitanBarsihanor (2016) tentang studi komparasi keterampilan sosial antara siswa sekolah dasar yang menggunakan sistem FDS dan reguler, Nilai rata-rata keterampilan sosial siswa SD yang menggunakan sistem FDS adalah 131,62 dan siswa SD reguler adalah 122,96. Selisih keduanya adalah: 8,66.

Berdasarkan latar belakang tersebut, bagaimanakah kemudian menemukan konsep FDS yang efektif dan konstruktif yang dapat berkontribusi pada meningkatnya kecerdasan spiritual siswa. Untuk menemukan jawaban membutuhkan kajian yang mendalam, tetapi secara teori merujuk pada teori Gardner, sebagaimana dikutip Colin Rose dan Malcom J. Nicholl (2002), bahwa setiap orang memiliki bermacam-macam kecerdasan, maka dengan adanya FDS diharapkan mampu menghasilkan siswa yang unik dan memiliki kecerdasan sesuai potensinya, khususnya dalam SQ.

Model FDS berbasis kecerdasan majemuk adalah sebuah model pembelajaran yang belum banyak disentuh oleh para peneliti sehingga belum banyak juga sekolah yang mengaplikasikan model pembelajaran ini. Hal tersebut dapat dilihat dari penelitian-penelitian terdahulu, di antaranya penelitian Wiwik Sulistyaningsing (dalam Utomo, 2017) yang menjelaskan bahwa FDS adalah sekolah yang mana sistem pembelajarannya bersifat integrated activity dan integrated curriculum, menjadikan anak mendapatkan materi yang utuh dan terintegrasi sehingga membutuhkan konsep yang matang agar outcome yang diharapkan dapat tercapai.

Penelitian ini dilakukan dalam empat tahap; define, design, develop (pengembangan) dan disseminate (penyebaran).Untuk dapat membuat langkah-langkah yang tepat dan valid dalam menghasilkan model pembelajaran yang dapat memfasilitasi peserta didik meningkatkan SQ dalam sistem FDS, maka diperlukan penelitian yang dapat menjawab permasalahan tersebut. Oleh karena itu, dipilihlah SDIT AlAmbari, SDTQ Al-Ikhlas, dan SDIT Harapan Umat sebagai mitra dan sampel dalam penelitian ini.

\section{METODE PENELITIAN}

Jenis penelitian yang digunakan adalah penelitian dan pengembangan R\&D (research and development). Tahapan penelitian terdiri dari dua tahap, mengacu pada langkah R\&D menurut Borg \& Gall (1983) tahap pertama adalah define, dengan melakukan studi pendahuluan untuk memperoleh informasi yang dibutuhkan, yaitu malalui studi pustaka, observasi, dan wawancara kepada guru dan siswa dari tiga sekolah yang menerapkan FDS yaitu SD IT Al-Ambari, SD TQ Al-Ikhlas, dan SD IT Harapan Umat.Kedua, men-design produk yang berupa bahan ajar, dan divalidasi oleh guru ahli dari tiga sekolah tersebut. Ketiga, develop (pengembangan) bahan ajar setelah menerima masukan dari ahli materi untuk penyempurnaan. Keempat, produk yang telah dinilai layak disseminate (disebarkan). Dalam mengukur tingkat kecerdasan spiritual siswa digunakan kriteria skala limayang kemudian dikonversikan menjadi data kualitatif, dengan acuan rumus yang diadaptasi dari (Azwar, 2012). 
Muh. Luqman Arifin, dan Adnan Yusufi

MODEL FULL DAY SCHOOL BERBASIS KECERDASAN MAJEMUK UNTUK MENINGKATKAN ... REFLEKSI EDUKATIKA : Jurnal Ilmiah Kependidikan 10 (1) Desember 2019. Hlm. 105-112

Tabel 1. Konversi Skala 5 Saifuddin Azwar

\begin{tabular}{ccc}
\hline No & Interval Skor & Nilai \\
\hline $\mathbf{1}$ & $\mathrm{X}>\mathrm{Xi}+1,5 \mathrm{Sbi}$ & $\mathrm{E}$ \\
& & Tidak Baik \\
\hline \multirow{2}{*}{} & $\mathrm{Xi}+\mathrm{Sbi}<\mathrm{X}<\mathrm{Xi}+$ & $\mathrm{D}$ \\
& $1,5 \mathrm{Sbi}$ & Kurang \\
\hline $\mathbf{3}$ & $\mathrm{Xi}-0,5 \mathrm{Sbi}<\mathrm{X}$ & $\mathrm{C}$ \\
& $\mathrm{Xi}+1,5 \mathrm{Sbi}$ & Cukup \\
\hline $\mathbf{4}$ & $\mathrm{Xi}-1,5 \mathrm{Sbi}<\mathrm{X}$ & $\mathrm{B}$ \\
& $\mathrm{Xi}-0,5 \mathrm{Sbi}$ & Baik \\
$\mathbf{5}$ & $\mathrm{X}<\mathrm{Xi}-1,5 \mathrm{Sbi}$ & A \\
& & Sangat Baik \\
\hline
\end{tabular}

Keterangan:

$\mathrm{X}=$ Skor empiris (skor aktual)

$\mathrm{Xi}=$ rerata ideal $=1 / 2($ skor maksimal + skor minimal)

Sbi $=$ simpangan baku ideal $=1 / 6$ (skor maksimal - skor minimal).

\section{HASIL DAN PEMBAHASAN}

Hasil penelitian diperoleh informasi bahwa ada tiga sekolah yang menerapkan sistem FDS, yaitu SDIT Al-Ambari, SDTQ Al-Ikhlas, dan SDIT Harapan Umat yang ketiganya berada di Kabupaten Brebes. Data tersebut diperkuat dengan observasi dan wawancara dengan para guru yang mengajar di sana. Ketiga sekolah tersebut sama-sama berbasis Islam dan memiliki penciri memiliki muatan kurikulum khas. SDIT Al-Ambari fokus pada kepribadian dan karakter, SDTQ Al-Ikhlas fokus pada kemampuan hafalan Al-Qur'an, dan SDIT Harapan Umat pada karakter dan kemampuan sains. Ketiga sekolah sama-sama memiliki moto pada penanaman akhlak dan prilaku peserta didik melalui integrasi kegiatan kurikuler dan co-kurikuler.

Dari aspek kurikulum, ketiganya samasama menganut kurikulum pemerintah plus kurikulum khas. Kurikulum khas inilah yang menjadi penciri dan pembeda dari ketiga sekolah tersebut dari sisi muatan lokal. Akan tetapi, umumnya kurikulum khas tersebut adalah berupa materi keagamaan dan pembiasaan ibadah, seperti tilawah, baca al-Qur'an, dan shalat Dhuha berjamaah.

Dari aspek tenaga pengajar, ketiganya memiliki guru kualifikasi sarjana pendidikan, meski ada satu sekolah yang tidak mempersyaratkan berpredikat sarjana asalkan terbukti memiliki kepribadian, kualitas dan kemampuan dengan mekanisme perekrutan calon guru yang mereka miliki.

Dari aspek sarana dan prasarana, SDIT Harapan Umat adalah sekolah yang memiliki sarana paling lengkap terlebih sekolah tersebut adalah yang paling tua. Selanjutnya adalah SDTQ Al-Ikhlas, meski paling baru, tetapi sarana yang mereka miliki relatif lengkap. Terakhir, SDIT Al-Ambari, meski fasilitas belum terlalu lengkap, tetapi SD ini mampu memanfaatkan wahana di sekitar sekolah sebagai media pembelajaran yang kemudian mereka sebut, out door sehingga keterbatasan ini mampu mereka selesaikan.

Dalam wawancara dengan guru diinformasikan bahwa ketiga sekolah tersebut belum memiliki model multiple intelligence (MI), yang meliputi komponen input-prosesoutput yang memudahkan guru mengindentifikasi peserta didik ketika masuk sebagai siswa. Tiga komponen tersebut belum bisa dilaksanakan sebagai sebuah desain dalam pre dan proses pembelajaran. Sebagai sebuah komponen penting, input yang dapat berupa tes minat bakat untuk mengindentifikasi kecenderungan bakat siswa baru dilaksanakan oleh satu sekolah, meskipun sekolah yang menerapkan pun, belum memanfaatkan komponen tersebut sebagai referensi dalam menemukan metode pembelajaran yang tepat. Jadi, ketiga sekolah dalam menggunakan strategi pembelajaran langsung masuk pada komponen proses sesuai output lulusan yang mereka harapkan.

Dari semua data yang dapat dihimpun, peneliti kemudian merancang model yang disebut diagram input-proses-output. Diagram tersebut diperuntukkan untuk mengembangkan Kecerdasan Majemuk (KM) siswa, melalui diagram yang setiap tahapan jika dilakukan dengan benar akan memberikan kontribusi pada MI.

Dalam penelitian ini, peneliti fokus pada diagram proses, meski kegiatan dalam ranah proses seperti kegiatan ekstrakurikuler, sains club, olah raga,seni, music, tahfizh juga telah dijalankan dan beberapa peserta berhasil memenangkan lomba pada bidang yang diikuti. Di di sini peneliti juga akan fokus pada tahapan proses, yaitu bagaimana melalui treatment, perlakukuan, usaha sadar dan terencana dalam bentuk pemberian materi dalam kurikulum. Perlakuan tersebut dengan cara memberikan materi 'bahan ajar' kepada siswa. Tahapan proses dipilih untuk mengetahui sejauh mana perkembangan MI siswa by design, alias tidak berkembang alami melalui kegiatan yang terselenggara di sekolah dan pada program ekstrakurikuler. Oleh karena itu, model ini kemudian ingin diujicobakan dan dikembangkan dengan melalui validasi ahli.

Adapun tema yang dipilih adalah 'jujur', 'taat dan patuh kepada orang tua dan guru', serta 
Muh. Luqman Arifin, dan Adnan Yusufi

MODEL FULL DAY SCHOOL BERBASIS KECERDASAN MAJEMUK UNTUK MENINGKATKAN ... REFLEKSI EDUKATIKA : Jurnal Ilmiah Kependidikan 10 (1) Desember 2019. Hlm. 105-112

'toleran kepada orang lain.' Ketiga tema tersebut adalah pengembangan dari pelajaran Pendidikan Agama Islam dan Budi Pekerti untuk anak SD, yang substansi dan tujuannya diorientasikan pada pembentukan akhlak yang mulia, penuh kasih sayang, kepada segenap unsur alam semesta kepada peserta didik. Hal tersebut selaras dengan Kurikulum 2013 yang dirancang untuk mengembangkan kompetensi yang utuh antara pengetahuan, keterampilan, dan sikap. Peserta didik tidak hanya diharapkan bertambah pengetahuan dan wawasannya, tetapi juga meningkat kecakapan dan keterampilannya serta semakin mulia karakter dan kepribadiannya atau berbudi pekerti luhur.

Bahan ajar yang dikembangan meliputi silabus, rencana pelaksanaan pembelajaran (RPP), lembar kerja peserta didik (LKPD) dan rubrik penilaian. Pengenbangan bahan ajar berdasarkan model pengembangan 4-D atau model Thiagraja yang meliputi 4 tahap yaitu perencanaan, perancangan, pengembangan, dan penyebaran.

Bahan ajar yang telah disusun kemudian divalidasi oleh ahli dari guru SD yang mengajar di tiga sekolah tersebut. Data tersaji sebagai berikut.

1. Data Validasi Bahan Ajar

Buku ajar yang disusun telah divalidasi oleh ahli yang terdiri dari tiga guru di sekolah yang menjadi objek penelitian dan memberikan penilainan rata-rata 4.3 dengan predikat "Sangat Baik." Secara kuantitatif angka menunjukkan kelayakan produk.

Adapun komponen yang dinilai ada dua, yaitu 1) komponen aspek pembelajaran yang meliputi a) kesesuaian materi dengan kompetensi inti, b) kesesuaian materi dengan kompetensi dasar, c) ketepatan penggunaan contoh yang kontekstual (sesuai dengan kehidupan seharihari), d) bahasa yang digunakan mudah dipahami, e) kesesuaian petunjuk dengan target capaian pembelajaran, f) kesesuain silabus dengan standar kurikulum 2013, g) kesesuain RPP dengan standar kurikulum 2013. Adapun komponen ke-2), prinsip-prinsip model yang meliputi, a) kesesuaian pendekatan Kecerdasan Majemuk dalam memfasilitasi kecerdasan spiritual siswa, b) Nila-nilai yang terkandung dalam materi dapat meningkatkan kecerdasan spiritual, c) Lembar kerja peserta didik (LKPD) dapat mengukur kecerdasan spiritual siswa, d) Kesesuaian Tema/Topik yang digunakan dengan karaktersitik siswa, e) Kesesuaian tema yang digunakan sebagai sumber belajar untuk peningkatan kecerdasan majemuk.
Tabel 2. Konversi Penilaian Validator

\begin{tabular}{lcccc}
\hline No & Validator & $\begin{array}{c}\text { Rerata } \\
\text { Penilaian } \\
\text { Produk }\end{array}$ & $\begin{array}{c}\text { Interval } \\
\text { Skor }\end{array}$ & Nilai \\
\hline 1. & $\begin{array}{c}\text { Guru SDIT } \\
\text { Harapan } \\
\text { Umat }\end{array}$ & 3.9 & $\begin{array}{c}\mathrm{Xi}-1,5 \\
\mathrm{Sbi}<\mathrm{X}< \\
\mathrm{Xi}-0,5 \\
\text { Sbi }\end{array}$ & $\mathrm{B}$ \\
& & & $\begin{array}{c}\mathrm{X}<\mathrm{Xi}- \\
1,5 \mathrm{Sbi}\end{array}$ & $\mathrm{A}$ \\
\hline 2. & $\begin{array}{c}\text { Guru SDIT } \\
\text { al-Ambary }\end{array}$ & 4,7 & $\begin{array}{c}\mathrm{X}<\mathrm{Xi}- \\
1,5 \mathrm{Sbi}\end{array}$ & $\mathrm{A}$ \\
\hline 3. & $\begin{array}{c}\text { Guru } \\
\text { SDTQ Al- } \\
\text { Ikhlas }\end{array}$ & 4,2 & $\mathrm{~A}$ \\
\hline & $\begin{array}{c}\text { Rata-Rata } \\
\text { Total }\end{array}$ & $\mathbf{4 , 3 0 5 5 5 5 5 6}$ & &
\end{tabular}

Selain penilaian berupa angka, validator juga memberikan komentar dan saran yang berisi: a) Kompetensi Dasar (KD) untuk Kompentensi Inti belum semua muncul dalam silabus (RPS), b) indikator diambil dari KD, c) penilaian disesuaikan dari KD dan indikator, d) menyertakan referensi yang jelas, e) rubrik belum terinci. Komentar yang lain adalah model yang dikembangkan sangat representatif dan layak digunakan.

2. Data Kecerdasan Spiritual Siswa

Dalam memperoleh data hasil Kecerdasan Spiritual (KS) siswa, peneliti menggunakan angket penyatan pertama, tema 'jujur' sebanyak 5 pernyataan a) saya mengerjakan soal ujian secara mandiri, b) saya mengerjakan shalat lima waktu, c) saya jujur kepada bapak/ibu guru kalau lupa mengerjakan Pekerjaan Rumah (PR), d) saya akan bertanya kepada Bapak/Ibu guru kalau tidak paham pelajaran, e) saya harus mengatakan apa adanya kalau ditanya Bapak/Ibu guru. Kedua, tema 'hormat dan patuh pada orang tua dan guru' yang meliputi pernyataan, a) saya harus menyimak penjelasan yang disampaikan Bapak/Ibu guru, b) saya tidak pernah menolak jika diperintah orang tua, c) saya selalu izin kepada orang tua jika mau keluar rumah, d) saya tidak pernah mengerjakan yang dilarang orang tua, e) saya tidak pernah menolak jika diminta maju di depan kelas oleh Bapak/Ibu guru. Ketiga, tema 'indahnya saling menghargai' yang meliputi, a)saya tidak mengejek teman saya yang bodoh, b) saya harus menghormati jawaban teman saya meskipun salah, c)saya selalu memperhatikan kalau Bapak/Ibu guru sedang menjelaskan pelajaran, d) saya menghargai teman saya yang beragama yang berbeda dengan agama saya, e) saya selalu berkata sopan meski diejek oleh teman. 
Muh. Luqman Arifin, dan Adnan Yusufi

MODEL FULL DAY SCHOOL BERBASIS KECERDASAN MAJEMUK UNTUK MENINGKATKAN ... REFLEKSI EDUKATIKA : Jurnal Ilmiah Kependidikan 10 (1) Desember 2019. Hlm. 105-112

Bahan ajar yang meliputi angket pernyataan yang telah divalidasi secara bertahap dilakukan sesuai tahapan menurut Borg \& Gall, yaitu uji coba pendahuluanpada satu sekolah, yaitu di SD IT Al-Ambary siswa kelas V. Uji coba terbatas dilakukan untuk mengetahui hasil KS siswa. Hasil angket yang diisi oleh sebanyak 19 siswa mendapatkan skor 3,5 masuk kategori baik. Selanjutnya, karena angket dinilai valid masuk pada tahapan berikutnya, yaitu uji coba operasional yang dilakukan di dua sekolah, yaitu SDTQ Al-Ikhlas dan SDIT Harapan Umat. Hasil dari angket, di SD pertama yang diiikuti oleh sejumlah 18 siswa, mendapatkan skor 4,0 masuk kategori "Baik Sekali," dan SD kedua, yang diikuti 21 siswa, mendapat skor 4 masuk kategori "Baik Sekali".

Jadi, hasil kecerdasan spiritual yang dilakukan di tiga Sekolah, SDIT Al-Ambary, SDTQ Al-Ikhlas, dan SDIT Harapan dengan menggunakan angket pernyataan yang terdiri dari komponen sub tema "Orang Jujur Disayang Allah","Hormat Dan Patuh Pada Orang Tua Dan Guru”, "Indahnya Saling Menghargai"masing-masing komponen terdiri dari 5 soal sehingga jumlah soal 15 buah.

Tabel 3. Rerata Hasil Kecerdasan Spiritual Siswa.

\begin{tabular}{|c|c|c|c|}
\hline No & Sekolah & Rerata Hasil & Kategori \\
\hline 1. & $\begin{array}{c}\text { SDIT Al- } \\
\text { Ambary }\end{array}$ & 3,5 & Baik \\
\hline 2. & $\begin{array}{c}\text { SDTQ Al- } \\
\text { Ikhlas }\end{array}$ & 4,2 & Baik Sekali \\
\hline 3. & $\begin{array}{c}\text { SDIT Harapan } \\
\text { Umat }\end{array}$ & 4 & Baik Sekali \\
\hline & Rat-Rata & $\mathbf{3 , 9}$ & Baik \\
\hline
\end{tabular}

\section{Pembahasan}

Terdapat tiga sekolah yang dijadikan objek dalam penelitian ini, yaitu SDIT AlAmbari, SDTQ Al-Ikhlas, dan SDIT Harapan Umat, yang sama-sama menerapkan FDS. FDS sebagai sebuah sistem yang diterapkan pada satuan pendidikan menurut beberapa peneliti efektif, tetapi menurut yang lain sebaliknya. Dalam penelitian ini, peneliti akan menjawab pertanyaan, bagaimana FDS berbasis Kecerdasan Majemuk (KM) dapat meningkatkan kecerdasan spiritual siswa. Dalam menjawab permasalahan tersebut, peneliti melakukan penelitian pada sekolah yang menerapkan FDS dengan mengambil sampel tiga sekolah. Pertama-tama peneliti ingin melihat bagaimana desain pembelajaran yang digunakan pada sekolah tersebut. Dalam memperoleh data peneliti menggunakan metode observasi dan wawancara pada tiga sekolah tersebut. Informasi diperoleh bahwa tiga sekolah telah memiliki model dalam melaksanakan FDS dalam mencapai anak didik yang cerdas secara kognitif, afektif, dan psikomotorik. Ketiga sekolah tersebut samasama mengusung konsep Islam; bedanya yang dua mengambil icon Islam Terpadu (IT) dan satunya Takhasus Al-Qur'an (TQ). Kurikulum yang dikembangkanpun sama, yaitu perpaduan kurikulum nasional dan kurikulum khas sekolah yang menitikberatkan pada penanaman akhlak dan kepribadian. Secara umum, prestasi akademik dan non akademik dari ketiga sekolah tersebut baik, demikian juga non akademik, selian juga kepribadian dan karakter siswa.

Sesuai standar lulusan yang dicanangkan sebagai bentuk pengejawentahan visi dan misi sekolah, kualitas dari hasil pembelajaran memuaskan. Akan tetapi, apakah kemudian kualitas tersebut sesuai minat dan bakat siswa, inilah yang masih menyisakan pertanyaan. Sebagaimana data yang diperoleh, sekolahsekolah tersebut belum memiliki desain MI mengacu pada diagram input-proses-output. Padahal, merujuk pada pendapat Gagne dalam Gredeer dan Margaret (1986) tidak bisa lepas dari tiga komponen, internal (internal conditions of learning), eksternal (external conditions of learning), hasil belajar (outcomes of learning), atau bisa disederhanakan dengan tahapan input, proses, sampai output (IPO). Diagram ini akan membantu sekolah bagaimana mengelola potensi dan mental siswa secara sistemik dengan pendekatan MI sehungga rasa jenuh dan bosan yang berpotensi terjadi pada diri bisa dihindari. Sebagaimana diketahui bosan umumnya terjadi secara mental karena adanya faktor yang kurang disukai, sedangkan secara generic minat setiap anak berbeda. Oleh karena itu, penting sekolah memperhatikan diagram IPO, sebab dalam sebuah penelitian Widodo (2019) prestasi akademik dan non akademik yang tinggi, yaitu dengan skor antara 55\%-78\% dalam FDS dipengaruhi instrumental input siswa yang 97,7\% telah menempuh pendidikan Taman KanakKanan dan Pendidikan Anak Usia Dini. Hal ini menegaskan bahwa diagnosa dini kepada kepribadian, kecenderungan, mental, dan minat peserta didik bersifat vital.

Diagnosa melalui tahapan input memberikan kesempatan kepada pendidik menetapkan metode, strategi, dan media dalam melakukan pembelajaran yang bersifat based on demand siswa. Tidak terjadi generalisasi strategi untuk semua siswa dengan kecerdasan yang 
berbeda-beda. Dijelaskan oleh Jasmine (2007) bahwa menggunakan pendekatan KM berarti memberikan pengakuan terhadap perbedaan individual. Ini menjadi penting sebagaimana disebut dalam penelitian Intan Rahmawati dkk (2019) memahami konsep KM akan menuntun guru atau pendidik menyediakan fasilitas dan aktivitas yang menarik, serta terintegrasi demi menghindari keterlambatan pada perkembangan fisik yang berpengaruh pada perkembangan emosi, kepribadian, kreativitas, dan sosial anak. Oleh karena itu, dalam menjawab permasalahan tersebut, perlu dikembangkan pendekatan KM merujuk pada teori Gardner.

Dalam mengaplikasikan teori Gardner dapat dilakukan dengan melakukan penelitian R\&D mengacu pada tahapan Borg \& Gall (1983). Pengembangan yang dipilih peneliti adalah produk yang berupa "bahan ajar" yang termasuk tahap proses dalam diagram IPO. Produk dirancang setelah terlebih dahulu dilakukan studi pendahuluan untuk mengetahui kondisi dan karakteristik siswi, sehingga materi yang dipilih sesuai. Bahan ajar yang dipilih memiliki kesamaan karakteristik dengan kurikulum 2013, yaitu KD, KI, materi, dan sumber belajar. Dari 4 KI yang dipilih adalah 2 $\mathrm{KI}$, yaitu K1, yang berisi menerima, menjalankan, dan menghargai ajaran agama yang dianutnya, KI 2, menunjukkan perilaku jujur, disiplin, tanggung jawab, santun, peduli, dan percaya diri dalam berinteraksi dengan keluarga, teman, guru, dan tetangganya serta cinta tanah air. Ini sesuai dengan materi pembelajaran untuk kelas V Sekolah Dasar (SD). Dengan memperhatikan aspek-aspek yang perlu dipenuhi dalam standar 'bahan ajar', bahan ajar kemudian dilakukan penilain oleh validator. Validator memberi skor rata-rata 4,3 dengan disertai masukan dan komentar. Dilihat dari content bahan yang memuat dua komponen, yaitu "aspek pembelajaran" dan "prinsip-prinsip model MI untuk meningkatkan KS siswa" bahan ajar dinilai layak digunakan. Alasan layak di sini karena muatan materi dalam bahan ajar diselaraskan dengan standar KD dan KI pada kurikulum. Materi, contoh, bahasa sudah sesuai dengan standar kurikulum 2013, serta karakteristik dan kebutuhan siswa. Demikian juga, pendekatan yang digunakan sudah memfasilitasi siswa untuk meningkatkan kecerdasannya.

Pengembangan buku ajar sesuai karakteristik siswa sangat penting, seperti dikutip oleh Lucy (2010) ada sekitar 40\% anak berbakat di sekolah, tetapi tidak mampu berprestasi, karena anak tidak mendapatkan pendidikan sesuai bakat dan minatnya. Penelitian ini fokus pada tahap "proses" mengacu pada diagarm IPO, yaitu bagaimana peserta didik diperlakukan dengan tindakan tertentu kemudian bagaimana hasil dari tindakan tersebut dalam peningkatan aspek afektifnya. Secara prinsip elemen dalam bahan ajar sudah sesuai dengan tahapan perkembangan mental siswa sebab sudah mengacu kurikulum SD. Bahan ajar ini pun kemudian divalidasi ahli, yaitu guru SD di tiga sekolah yang memberikan penilaian masuk kategori "Baik" serta layak dan representatif digunakan dalam pembelajaran di SD yang menerapkan FDS.

Tabel 4. Rerata Penilaian Validator

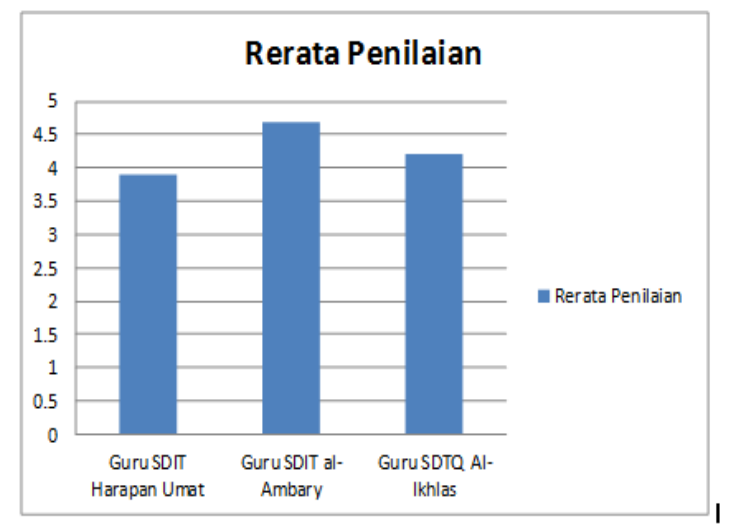

Bahan ajar merupakan sumber informasi materi yang penting bagi guru maupun siswa. Bahan ajar merupakan materi pelajaran yang disusun secara lengkap, sistematis, unik, dan spesifik, serta dirancang untuk mencapai kompetensi tertentu.

Materi dan buku ajar yang tepat, efektif untuk mencapai tujuan pembelajaran. Dan pembelajaran yang tepat pada sekolah yang siswanya memiliki beragam kecerdasan adalah dengan pendekatan kecerdasan majemuk, sebab dengan pendekatan itu, sebagaimana penelitian yang dilakukan Mila Dwi Candra, yang berjudul, "Penerapan Pembelajaran Berbasis Multiple Intelligences Pada Siswa Kelas V di SD Juara Gondokusuman Yogyakarta" bahwa pembelajaran berbasis multiple intelligences membuat guru bisa melakukan penilaian autentik yang mencakup ranah, kognitif, afektif, dan psikomotorik.

Bahan ajar yang telah mendapatkan penilaian validator kemudian digunakan dalam pembelajaran siswa kelas $\mathrm{V}$ yang menjadi objek. Sesuai tahapan penelitian R\&D maka tahapan 
Muh. Luqman Arifin, dan Adnan Yusufi

MODEL FULL DAY SCHOOL BERBASIS KECERDASAN MAJEMUK UNTUK MENINGKATKAN ... REFLEKSI EDUKATIKA : Jurnal Ilmiah Kependidikan 10 (1) Desember 2019. Hlm. 105-112

yang dilakukan adalah uji coba terbatas pada satu sekolah, yaitu di SD IT Al-Ambary. Tahapan ini dilakukan untuk mengetahui kelayakan model yang telah dikembangkan dan mendapat masukan dari ahli. Hasil angket yang diisi oleh sebanyak 19 siswa mendapatkan skor 3,5 masuk kategori baik. Alasan sekolah ini dijadikan sebagai 'uji coba' pendahuluan adalah sekolah ini berapa pada posisi tengah, tidak paling tua dan tidak paling baru, dilihat dari tahun berdirinya, kemudian alasan lain, secara kelengkapan fasilitas dan sarana dan pra sarana juga dalam posisi di tengah dibandingkan dengan dua sekolah lainnya. Selanjutnya, karena angket dinilai valid masuk pada tahapan berikutnya, yaitu uji coba operasional yang dilakukan di dua sekolah, yaitu SDTQ Al-Ikhlas dan SDIT Harapan Umat. Hasil dari angket, di SD pertama, yang diiikuti oleh sejumlah 18 siswa, mendapatkan skor 4,0 masuk kategori "Baik Sekali," dan SD kedua, yang diikuti 21 siswa, mendapat skor 4 masuk kategori "Baik Sekali".

Secara teoretik langkah-langkah dalam pembelajaran dimulai dengan pendahuluan, kegiatan inti, dan penutup. Tahapan berikutnya adalah tes angket pernyataan terkait tema yang telah ditentukan. Jadi, hasil KS yang dilakukan di tiga Sekolah, SDIT Al-Ambary, SDTQ AlIkhlas, dan SDIT Harapan dengan menggunakan angket pernyataan yang terdiri dari komponen sub tema "Orang Jujur Disayang Allah","Hormat Dan Patuh Pada Orang Tua Dan Guru", "Indahnya Saling Menghargai" masing-masing komponen terdiri dari 5 soal sehingga jumlah soal 15 buah terbukti efektif dengan skor yang 'Baik.'

Tabel 5. Rerata Kecerdasan Spiritual Siswa.

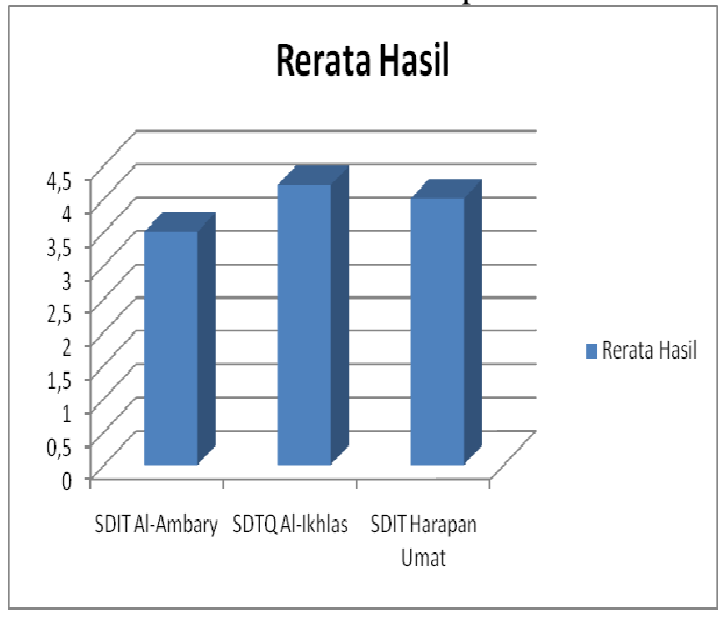

Hasil penelitian menunjukkan rerata skor tingkat kecerdasan siswa adalah 3,9 atau 'Baik'.
Tingginya nilai hasil KS siswa dimungkinkan ada pengaruh faktor lain, yaitu sekolah tersebut merupakan sekolah yang berbasis Islam dan pembentukan akhlak merupakan target capaian mereka, yang disesuaikan dengan visi dan misi ditambah kuantitas jam pelajaran. Hal ini membuka peluang penelitian berikutnya, dengan objek di sekolah umum.

KS dinilai penting, mengingat $\mathrm{KS}$ berperan sebagai landasan untuk memfungsikan Kecerdadasan Intelektual (KI) dan Kecerdasan Emosional (KE) sebagaimana dijelaskan dalam penelitian Ahmad Zarkasyi (2015), dan peserta didik harus memadukan ketiganya agar dia memiliki konsep dunia atau kepekaan emosi dan intellegence yang baik (EQ dan IQ) sekaligus penguasaan ruhiyah vertikal atau SQ (Spiritual Quotient). Sebagaimana dijelaskan dalam penelitian Zamzami Sabik dkk (2012) bahwa semakin tinggi kecerdasan spiritual siswa maka semakin tinggi perilaku prososialnya.

Berdasarkan paparan di atas, disimpulkan bahwa penelitian ini memberikan kontribusi pada pengembangan R\&D bahwa sekolah yang menerapkan FDS terbukti efektif dan dapat menekan aspek kejenuhan siswa, selama didesain dengan memperhatikan diagram IPO, dan 'pemberian bahan ajar' efektif dan mampu meningkatkan kecerdasan spiritual siswa.

\section{SIMPULAN}

Model full day school berbasis kecerdasan majemuk yang meliputi komponen input, proses, dan output dengan focus pada komponen proses, yang berupa "bahan ajar" dalam meningkatkan kecerdasan spiritual siswa layak diujicobakan berdasarkan penilaian validator dengan hasil rata-rata 4,3 atau dengan predikat "A" Sangat Baik. Dan hasil tes kecerdasan spiritual kepada siswa dari tiga sekolah, yaitu SDIT Al-Ambari, SDTQ Al-Ikhlas, dan SDIT Harapan Umat melalui tes angket diperoleh hasil rata-rata 3,9 masuk kategori "Baik."

\section{DAFTAR PUSTAKA}

Azwar, Saifuddin. 2012. Penyusunan skala psikologis. Yogyakarta: Pustaka Pelajar Offset.

Barsihanor, B., dan Hafiz, A. 2016. Studi Komparasi Keterampilan Sosial antara Siswa Sekolah Dasar yang Menggunakan Sistem Full Day dan Reguler. Muallimuna Jurnal Madrasah Ibtidaiyah, 2(1), 95103. 
Muh. Luqman Arifin, dan Adnan Yusufi

MODEL FULL DAY SCHOOL BERBASIS KECERDASAN MAJEMUK UNTUK MENINGKATKAN ... REFLEKSI EDUKATIKA : Jurnal Ilmiah Kependidikan 10 (1) Desember 2019. Hlm. 105-112

Borg, W.R. \& Gall, M.D. 1983. Educational Research: Longman, New York London.

Colin Rose dan Malcom J. Nicholl. 2002. Accelerated Learning For the 21st Century, Cara Belajar Cepat XXI. Bandung: Nuansa.

Dara, Y. P., \& Rahma, U. 2019. Pemahaman Konsep Belajar untuk Mengasah Kecerdasan Majemuk: Pendekatan Penelitian Tindakan. Psycho Idea, 17 (1), $42-51$.

Gardner, Howard. 1983. Frames of Mind: Tbe Theory of Multipk Intelligenees. New York: Basic Books.

Gredeer, B., dan Margaret, E. 1986. Learning and Instruction: Theory into Practice. New York: Macmillan Publising.

Halik, A. 2017. Mencari Format Pendidikan Anak Yang Ideal (Kritik Terhadap Konsep Full-Day School). TADRIS: Jurnal Pendidikan Islam, 11 (2), 132-148.
Jasmine, J. 2007. Panduan Praktis Mengajar Berbasis Kecerdasan Majemuk. Bandung: Nuansa.

Nggermanto, Agus. 2002. Quantum Quotient (Kecerdasan Quantum); Cara Cepat Melejitkan IQ, EQ dan SQ, secara Harmonis. Bandung: Nuansa Cendekia.

Sismanto. 2007. Awal Munculnya Sekolah Unggulan, 'Artikel'.

Widodo, M. 2019. Evaluasi Program Pendidikan Full Day School di Sekolah Dasar Islam Terpadu Hidayatullah Yogyakarta. Jurnal Tarbiyatuna, 10(1), 1-20.

Zarkasyi, A. 2016. Integrasi Peran IQ, EQ dan SQ dalam Regulasi Hukum Islam. Qolamuna: Jurnal Studi Islam, 1(2), 223-244.

Sabiq, Z. 2012. Kecerderdasan Emosi, Kecerdasan Spiritual dan Perilaku Prososial Santri Pondok Pesantren Nasyrul Ulum Pamekasan. Persona: Jurnal Psikologi Indonesia, 1(2). 